\title{
Characteristics of desorption gas of lacustrine shale in the Ordos Basin, China
}

\author{
JING Li ${ }^{1}$, SHIXIN ZHOU ${ }^{1}$ \\ ${ }^{1}$ Northwest Institute of Eco-Environment and Resources, \\ Chinese Academy of Sciences, Lanzhou, China
}

Desorption gases of four lacustrine shallow shale cores from the Triassic Yanchang formation of the Ordos Basin, China were collected, and their molecular and carbon isotope compositions were analyzed in this study. Results show that hydrocarbon gases in the desorption gases of the studied shale samples are dominated by methane, the content of which ranges from $23.33 \%$ to $35.73 \%$ with an average of $29.98 \%$. Ethane also has a relatively high content, which ranges from $2.65 \%$ to $20.34 \%$ with a mean value of $14.22 \%$. The composition of hydrocarbon gases decreases with the increasing of carbon number. The dryness coefficient $\left(\mathrm{C}_{1} / \mathrm{C}_{1-5}\right)$ of the desorption gases range from $0.45-0.82$ with an average of 0.58 . The $\delta^{13} \mathrm{C}$ values for hydrocarbon gases increase with increasing carbon number. The $\delta^{13} \mathrm{C}$ value for methane range between $-57.15 \%$ and $-53.71 \%$ with an average of $-55.25 \%$, which for ethane and propane are $49.24 \%$ to $-47.20 \%$ and $-37.63 \%$ to $-34.61 \%$ respectively. According to gas geochemical characteristics, the hydrocarbon gases generally derived from a mixed origin with primary contribution from thermogenic processes. Desorption gases of sample YK-340.7 could experience biodegradation for its relatively high dryness coefficient and $\left(\mathrm{iC}_{4} \mathrm{H}_{10}+\mathrm{iC}_{5} \mathrm{H}_{12}\right) /\left(\mathrm{nC}_{4} \mathrm{H}_{10}+\mathrm{nC}_{5} \mathrm{H}_{12}\right)$ value. A significant depletion of ${ }^{13} \mathrm{C}$ for methane was observed during desorption process, the reason for which could be differences in molecular mobility of the ${ }^{12} \mathrm{CH}_{4}$ and ${ }^{13} \mathrm{CH}_{4}$. Changes in the $\delta^{13} \mathrm{C}_{\text {ethane }}$ and $\delta^{13} \mathrm{C}_{\text {propane }}$ during desorption process are week. 